\title{
Hysteroscopy: A necessary method for detecting uterine pathologies in post-menopausal women with abnormal uterine bleeding or increased endometrial thickness
}

\section{Histeroskopi: Anormal uterin kanaması olan veya artmış endometrial kalınlı tanısı konmuş post-menopozal kadınlarda uterin patolojilerini tespit etmek için gerekli bir yöntem}

\author{
Fatemeh Sarvi ${ }^{1}$, Ashraf Alleyassin ${ }^{1}$, Marzieh Aghahosseini1, Marzieh Ghasemi², Sima Gityl \\ 1 Tehran University of Medical Sciences Shariati Hospital, Clinic of Endocrinology and Infertility, Tehran, Iran \\ 2Zahedan University of Medical Sciences, Pregnancy Health Research Center, Department of Obstetrics and Gynecology, Zahedan, Iran
}

\begin{abstract}
Objective: To investigate the histologic and hysteroscopic findings of post-menopausal women with uterine bleeding and asymptomatic women with increased endometrial thickness equal or more than $5 \mathrm{~mm}$.

Materials and Methods: This cross-sectional study was performed between May 2014 and June 2015 on 110 post-menopausal women aged $40-82$ years. The women were divided into two groups: Women with abnormal uterine bleeding (AUB group) and asymptomatic women with increased endometrial thickness (asymptomatic group).

Results: Among the participants, 67 women had AUB and 43 women were asymptomatic. In the AUB group sensitivity, specificity, and positive and negative predictive values of hysteroscopy for normal findings were $98 \%, 100 \%, 100 \%$ and $90 \%$, respectively. In the asymptomatic group, the same parameters were $98 \%, 100 \%, 100 \%$ and $85 \%$, respectively. The sensitivity, specificity, and positive and negative predictive values of hysteroscopy for polyps and myomas were $100 \%$. Also, the sensitivity, specificity, and positive and negative predictive values were $100 \%$ in hyperplasia cases found during hysteroscopy in both groups.

Conclusion: Increased endometrial thickness in postmenopausal women with or without AUB is mostly due to benign lesions such as polyps and submucosal myomas. Hysteroscopy is a safe and reliable method for evaluating and treating these lesions.
\end{abstract}

Keywords: Abnormal uterine bleeding, endometrial thickness, post-menopause, hysteroscopy, endometrial biopsy

$\ddot{\mathrm{O} z}$

Amaç: Uterin kanaması olan post-menapozal kadınlarda ve artmış endometrial kalığı 5 mm ve üzeri olan asemptomatik olan kadınlarda histolojik ve histeroskopik bulguları incelemek.

Gereç ve Yöntemler: Bu kesitsel çalışma Mayıs 2014 ve Haziran 2015 yılları arasında, yaşları 40 ve 82 arasında olan 110 post-menopozal kadın üzerinde gerçekleştirilmiştir. Kadınlar iki gruba ayrılmıştır: Anormal uterin kanaması (AUK grubu) olan kadınlar ve artmış endometrial kalınlığı olan asemptomatik kadınlar (asemptomatik grup).

Bulgular: Katılımcılar arasından 67 kadında AUK mevcuttu ve 43 kadın asemptomatikti. AUK grubunda, normal bulgular için sensitivite, özgünlük, pozitif ve negatif belirleyicilik değerleri sırasıly \%98, \%100, \%100 ve \%90 idi. Asemptomatik grupta, aynı değerler sirasıly \%98, \%100, \%100 ve \%85 olarak bulundu. Polipler ve miyomlar için histeroskopinin sensitivite, özgünlük, pozitif ve negatif belirleyicilik değerleri \%100 olarak tespit edildi. Ayrıca, her iki grupta histeroskopi ile tespit edilen hiperplazi olgularında sensitivite, özgünlük, pozitif ve negatif belirleyicilik değerleri \%100 idi.

Sonuç: AUK olan veya olmayan post-menopozal kadınlarda artmış endometrial kalınlık çoğunlukla polipler ve submukozal miyomlar gibi benign lezyonlardan kaynaklanmaktadır. Bu lezyonları değerlendirmek ve tedavi etmek için histeroskopi güvenli ve güvenilir bir yöntemdir.

Anahtar Kelimeler: Anormal uterin kanama, endometrial kalınlık, post-menopoz, histeroskopi, endometrial biyopsi

Address for Correspondence/Yazıssma Adresi: Marzieh Ghasemi, MD,

Zahedan University of Medical Sciences, Pregnancy Health Research Center, Department of Obstetrics and Gynecology, Zahedan, Iran

Phone: +98 5432295715 E-mail: drghasemim@yahoo.com

Received/Geliș Tarihi: 02.07.2016 Accepted/Kabul Tarihi: 06.09.2016

${ }^{\oplus}$ Copyright 2016 by Turkish Society of Obstetrics and Gynecology

Turkish Journal of Obstetrics and Gynecology published by Galenos Yayınevi. 


\section{Introduction}

Abnormal uterine bleeding (AUB) is as any kind of uterine bleeding in terms of duration, frequency, and volume. In postmenopausal women, women without a menstrual cycle for one year, any bleeding is abnormal. Postmenopausal bleeding has different causes including endometrial atrophy, polyps, myomas, endometrial hyperplasia, and endometrial carcinoma. Endometrial carcinoma is the most common malignancy of genital organs in women in developed countries. About $80 \%$ of endometrial cancers in post-menopausal women occur at ages of 50 to 65 years(1). On the other hand $10 \%$ to $15 \%$ of women with post-menopausal bleeding have endometrial cancer(2,3). Therefore, it is important to evaluate AUB in postmenopausal women very carefully. Measurement of endometrial line thickness by transvaginal sonography (TVS) is the first step to determine the need for further evaluations to rule out malignancy in these patients ${ }^{(4)}$. In case of endometrial thickness more than 4-5 $\mathrm{mm}$ in TVS of patients with postmenopausal bleeding, more evaluation is required to rule out cancer. Considering these values, the incidence of endometrial cancer with measurements thinner than this cut-off point is less than $1 \%(5,6)$. There is no agreement on the described threshold of endometrial thickness to differentiate between normal and abnormal endometrial pathologies in postmenopausal women without bleeding $(7,8)$. Some guidelines and researchers have suggested that asymptomatic post-menopausal women with endometrial thickness of 4-5 mm or more do not need endometrial biopsy unless AUB occurs $(9,10)$. However, some researchers believe that postmenopausal endometrial thickness represents an increased risk of malignancy or other underlying pathologies, such as hyperplasia, polyps or myomas, and should be evaluated(11). Hysteroscopy is a precise, easy, and quick method to assess and identify any intrauterine pathology with which we are able to observe the whole endometrial cavity and take adequate biopsies of any suspicious lesions. This procedure has recently been suggested as the best available method to evaluate the uterine cavity of women with endometrial line thickness with or without $\mathrm{AUB}(12,13)$. Another advantage of hysteroscopy is the "see and treat" method in which simultaneous real-time macroscopic diagnosis of benign lesions and resection can be made $(1,14)$. This study was designed to investigate and compare the histologic and hysteroscopic findings of post-menopausal women with AUB and asymptomatic women with increased endometrial thickness.

\section{Materials and Methods}

This cross-sectional study was performed between May 2014 and June 2015 on post-menopausal women who were referred to a center in Tehran because of having endometrial thickness equal or more than $5 \mathrm{~mm}$ in TVS, with or without AUB. They were divided into two groups: women with AUB group and asymptomatic women with increased endometrial thickness (asymptomatic group). Menopause was defined as the absence of menstrual periods for more than 12 months. The study protocol was approved by our university's ethics committee. The inclusion criteria were: (1) being menopausal; (2) aged 4082 years; (3) having uterine bleeding; and (4) having increased endometrial thickness $(\geq 5 \mathrm{~mm})$. The exclusion criteria were: (1) using hormonal replacement therapy, anticoagulants or selective estrogen receptor modulators; (2) having vaginal bleeding with a known cause in the vagina or cervix; (3) having any adnexal abnormality in TVS; (4) having any kind of cancer; and (5) being menopausal because of ovarian surgery. All participants signed an informed consent form before participating in this study. Transvaginal ultrasound was done for all participants. Endometrial line thickness was measured at the thickest part in the longitudinal plan of TVS with $7.5 \mathrm{MHz}$ vaginal probe. The cut-off value of endometrial thickness was 5 $\mathrm{mm}$ or more. Adnexal regions also were assessed by TVS. If any mass or abnormality was observed in the adnexa, the woman was excluded from the study $(1,15)$. Of the 148 women who were referred to our center in the defined period, 110 women met the inclusion criteria. Among them, 67 women had AUB group and 47 women were asymptomatic with endometrial thickness (asymptomatic group).

Hysteroscopy was conducted in an outpatient setting with a 3.5-mm Storz hysteroscope and 30 degrees view by an operator with 8 years of experience in performing hysteroscopy. The media was normal saline and hysteroscopy was performed with or without complete or local anesthesia. The whole endometrial level and cavity were precisely and systematically evaluated using hysteroscopy. All findings were recorded accurately. Hysteroscopic findings were defined precisely based on the specific findings detected during the procedure. Normal hysteroscopic findings included a normal, non-vascular smooth level. Abnormal findings included polyps, submucosal myomas, endometrial hyperplasia, and endometrial cancer(16).

Hyperplasic endometrium was defined as endometrium that was highly vascular, thick, and polypoid in appearance. Endometrial grooves became visible whenever it was pressed by the hysteroscope. Presence of abnormal vascular pattern and irregular fragile polypoid tissue with bleeding necrosis was defined as a sign of endometrial carcinoma(17). Endometrial biopsy was performed for all participants with intrauterine lesions. Punch biopsies were conducted in women with atrophic endometrium who had no pathology in hysteroscopy. In women with premalignant or malignant lesions, targeted and random biopsies were performed. In women with polyps or myomas, the lesions were all resected using scissors or resectoscope, respectively. The biopsies were immediately placed in 10\% formaldehyde and sent to the pathology laboratory. The pathologist knew nothing of the hysteroscopic findings. Histologic findings were defined as the final exact diagnosis standard of the endometrial pathology. The pathologic findings between the two groups and the percentages of each finding were analyzed. The hysteroscopy's predictive value in endometrial lesions' diagnosis was assessed based on 
the sensitivity, specificity, and positive and negative predictive values $(18,19)$.

\section{Statistical Analysis}

Categorical and continuous variables are summarized as number (percentage) and mean, respectively. Hysteroscopy was considered as a screening test and endometrial biopsy as a standard. Data analysis was performed using the Statistical Package for Social Sciences (SPSS) version 20 (Chicago, IL, USA) by calculating sensitivity, specificity, and positive and negative predictive values.

\section{Results}

This study was conducted on post-menopausal women with a mean age of 57 years. Of the 110 participants with endometrial thickness equal or more than $5 \mathrm{~mm}, 67$ (60.9\%) had AUB. All 110 patients underwent hysteroscopy and endometrial biopsy. The hysteroscopic findings were categorized into five groups: normal, polyps, myomas, hyperplasia, and carcinoma (Table 1).

Table 1. Hysteroscopic findings of our study groups

\begin{tabular}{llll}
$\begin{array}{l}\text { Hysteroscopic } \\
\text { findings }\end{array}$ & AUB group & $\begin{array}{l}\text { Asymptomatic } \\
\text { group }\end{array}$ & Total \\
\hline Normal & 10 & 7 & $15.5 \%$ \\
Polyp & 30 & 23 & $48.2 \%$ \\
\hline Myoma & 13 & 7 & $18.2 \%$ \\
Hyperplasia & 11 & 5 & $14.5 \%$ \\
\hline Carcinoma & 3 & 1 & $3.6 \%$ \\
\hline Total & $67(60.9 \%)$ & $43(39.09)$ & $100 \%$ \\
\hline
\end{tabular}

AUB: Abnormal uterine bleeding

Table 2. Comparison of the results of hysteroscopy and histopathologic findings of abnormal uterine bleeding and asymptomatic groups
We compared the hysteroscopy and pathology results of all participants. Among 17 women who had normal hysteroscopy in both groups, one woman in each group had simple hyperplasia in histopathology and the other had atrophy (atrophy in our classification was part of normal results) (Table 2).

The most common finding on hysteroscopic evaluation was endometrial polyps in both groups $(44.1 \%$ and $53.5 \%$ in AUB and asymptomatic groups, respectively). There were a total of 55 polyps and 20 myomas in both groups, which were confirmed by histopathology. Hyperplasia was found in 16 participants (11 and 5 in AUB and asymptomatic groups, respectively). This was confirmed with histology. Eleven cases were simple hyperplasia and five were complex or atypical hyperplasia. Three women in the AUB group and one in the asymptomatic group were suspected of having carcinoma in the hysteroscopy. Regarding the AUB group, the sensitivity, specificity, and positive and negative predictive values of the hysteroscopic view for finding normal results were $98 \%, 100 \%$, $100 \%$ and $90 \%$, respectively. In the asymptomatic group these parameters were 98\%, 100\%, 100\% and 85\%, respectively (Table 3). The sensitivity, specificity, and positive and negative predictive values of hysteroscopy for polyps and myomas were 100\%. The sensitivity, specificity, and positive and negative predictive values were 100\% for detecting hyperplasia with hysteroscopy in both groups. The sensitivity, specificity, and positive and negative predictive values of hysteroscopy for detecting carcinoma in the AUB group were 100\%, 97\%, 33\% and 100\%, respectively (Table 3). All lesions occupying the uterus (53 polyps and 20 uterine myomas) were diagnosed using hysteroscopy.

\section{Discussion}

The average of life expectancy for women has increased in recent years because of improved quality of life. Also, the

\section{Histopathology \\ Hysteroscopy Polyp Myoma Simple hyperplasia Complex or atypical Carcinoma Atrophy or not satisfactory}

\section{AUB group}

Normal

Polyp

Myoma

Hyperplasia

Carcinoma

\section{Asymptomatic group}

Normal

Polyp

Myoma

Hyperplasia

Carcinoma
1

30

- 13

- $\quad-8$

8

$-$

$-$

3

2

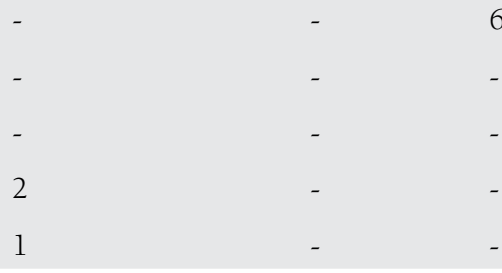

9

6
23

7

3

$-$

1

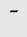

AUB: Abnormal uterine bleeding 
number of women older than 60 years is increasing. In spite of the absence of vaginal bleeding, these women may still have uterine pathologies such as endometrial hyperplasia, polyps, uterine fibroids, adenomiosis or even endometrial cancer, some of which can be malignant. Up to now, there is no common agreement regarding the clinical management of increased endometrial line thickness in post-menopausal women.

In our study, the common cause of endometrial thickening and AUB was endometrial polyp, which is consistent with other studies(1,20-24). Fortunately, polyps were not histologically malignant in our patients and this finding is in agreement with Loiacono et al.(24) study. Elfayomy et al.(2) showed that about $20 \%$ of polyps had malignant components hidden in their stem or center despite normal endometrial pathology in endometrial biopsy. Therefore, the authors suggested performing polypectomy via hysteroscopy in such women. On the other hand, 20 women of our study who only had increased endometrial thickness in TVS had submucosal myomas. Among them, 13 women had AUB and seven were asymptomatic. Therefore, we suggest that hysteroscopy be performed in all postmenopausal women with endometrial thickness $\geq 5 \mathrm{~mm}$ with or without AUB because of the successful resection of all polyps and sub-mucosal myomas without complications in these women $(1,17,24,25)$. It seems that more evaluations are needed in such cases because $86 \%$ of asymptomatic women with increased endometrial line thickness had underlying pathologic findings. This is in agreement with the studies of Loiacono et al.(24) and Hartman et al.(15).

In a study by Korkmazer et al.(20) on post-menopausal women with increased endometrial thickness, all intra-uterine lesions including polyps and submucosal myomas were diagnosed only via hysteroscopy. Curettage was not able to detect all lesions in their study; 25 of 93 women with atrophic endometrium had endometrial polyp in hysteroscopy and direct biopsy. Also, Lee et al.(25) compared biopsies obtained by curettage and hysteroscopy in post-menopausal women with bleeding. The authors concluded that performing curettage may not be reliable enough for evaluating endometrial pathology and suggested that endometrial biopsy with hysteroscopy must become the standard of diagnosis in these women. If endometrial biopsy is performed blindly, the detection of endometrial polyps or submucosal myomas might be missed. This leads to under diagnosis of this pathology during menopause. Therefore, the possibility of missing the underlying pathology will be eliminated by doing hysteroscopy $(20,26,27)$.

In our study, there was more endometrial hyperplasia in the AUB group than in the asymptomatic group (16\% vs. $11.6 \%$, respectively). Hysteroscopy in these patients enabled us to take targeted biopsies under direct vision. According to some studies, hysteroscopy did not have the desirable sensitivity compared with endometrial biopsy in women with endometrial hyperplasia. Thus, it was suggested to take endometrial biopsy under direct visualization during hysteroscopy $(2,28,29)$. The sensitivity, specificity, and positive and negative predictive values of hysteroscopy in diagnosing polyps, myomas, and endometrial hyperplasia were $100 \%$ in both groups. This finding is not in agreement with the diagnostic capability of hysteroscopy without biopsy in some studies $(2,30,31)$. Loiacono et al.(24) diagnosed three women with endometrial carcinoma while studying women who had normal hysteroscopic findings. The sensitivity and positive predictive value of hysteroscopy decreased to $63 \%$ and $77 \%$ in their malignant cases. Our findings showed the same decrease in positive predictive value of hysteroscopy, which is consistent with their study. A limitation of our study was the small number of participants. Thus, the hysteroscopic values for endometrial malignancies' diagnosis could not be assessed in the asymptomatic group. Of the women in AUB group, $1.5 \%$ had histologically confirmed endometrial cancer, and 5\% had atypical or complex hyperplasia. However, the positive predictive value of hysteroscopy for diagnosing carcinoma was 35\%. In some studies, the percentage of cancer in asymptomatic women with endometrial thickness more than $5 \mathrm{~mm}$ was $0.5-1.4 \%(32-35)$.

In a study by Elfayomy et al.(2) endometrial carcinoma was not reliably detected with hysteroscopy. In their study, 7 of 14 women (16.9\%) with endometrial cancer had suspicious findings in hysteroscopy, and no abnormality was found in the other half. According to the authors, the specificity

Table 3. Sensitivity, specificity, and positive and negative predictive values of hysteroscopy

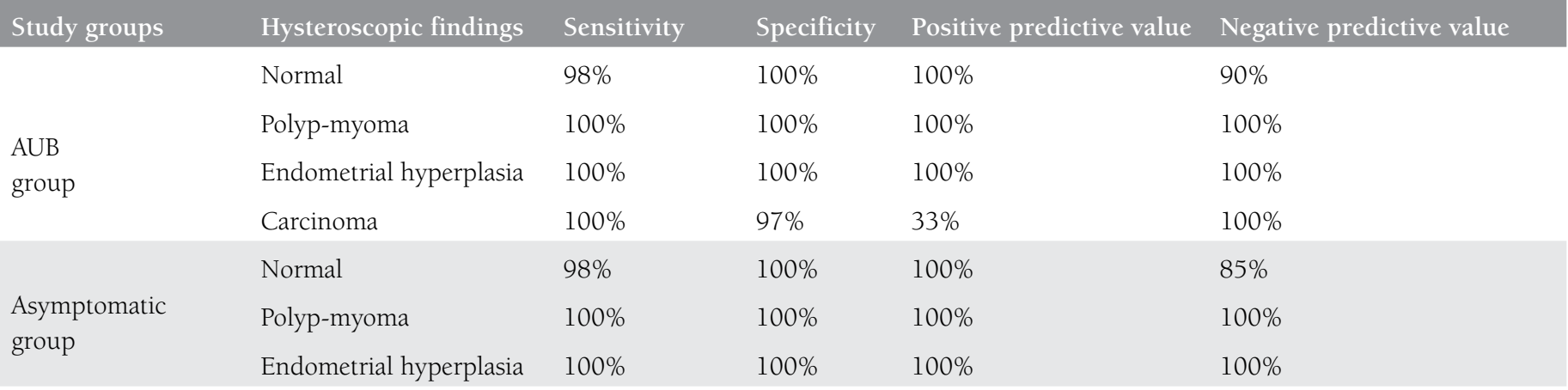

AUB: Abnormal uterine bleeding 
of hysteroscopy without biopsy was low in diagnosing endometrial cancer. This finding has been reported in other studies too(28,36). Therefore, it is recommended to perform a biopsy even if hysteroscopy finds no abnormality to increase the validity of hysteroscopy in diagnosing endometrial hyperplasia and cancer in post-menopausal women with bleeding or with endometrial line thickness of $5 \mathrm{~mm}$ or more in TVS. In our study, we compared the results of hysteroscopy with the results of histopathology in post-menopausal women with AUB or endometrial thickness of $5 \mathrm{~mm}$ or more. According to our findings and other studies, endometrial thickness is often due to the presence of benign lesions such as polyps and submucosal myomas $(2,7,24)$. Our study showed that hysteroscopy is a safe and reliable method for evaluating benign endometrium lesions. In our study, all studied women had a histologic confirmation of their diagnosis, which makes our findings a desirable and optimal reference. Hysteroscopy is more accurate than transvaginal ultrasound or dilatation and curettage in the diagnosis of endometrial polyps and other space-occupying endometrial lesions in post-menopausal women $(20,37)$. Considering the failure rate of ultrasound or dilatation and curettage in detecting some endometrial lesions, evaluation of the endometrial cavity by direct visualization is critical in diagnosing space-occupying lesions in postmenopausal women.

\section{Conclusion}

In contrast to some studies that state that doing hysteroscopy in asymptomatic post-menopausal women with increased endometrial thickness is not cost-efficient $(34,36,38)$ the present study showed that hysteroscopy is a safe and reliable procedure for evaluating benign lesions of endometrium such as polyps or submucosal myomas.

In order to rule out endometrial hyperplasia and cancer in postmenopausal women with bleeding or asymptomatic women with endometrial thickness, performing hysteroscopy and taking endometrial biopsies is recommended even if no lesion has been found. Further long-term prospective studies with more participants are necessary to find the optimum endometrial thickness in asymptomatic postmenopausal women.

\section{Acknowledgement}

The authors would like to thank Seyed Muhammed Hussein Mousavinasab for his sincere cooperation in editing this text.

\section{Ethics}

Informed Consent: All participants signed an informed consent before participating in this study.

Peer-review: Externally and Internally peer-reviewed.

\section{Authorship Contributions}

Surgical and Medical Practices: Fatemeh Sarvi, Marzieh Aghahosseini, Concept: Ashraf Alleyassin, Design: Marzieh Ghasemi, Fatemeh Sarvi, Data Collection or Processing: Fatemeh
Sarvi, Sima Gity, Analysis or Interpretation: Marzieh Ghasemi, Literature Search: Marzieh Ghasemi, Sima Gity, Fatemeh Sarvi, Writing: Marzieh Ghasemi, Sima Gity.

Conflict of Interest: No conflict of interest was declared by the authors.

Financial Disclosure: The authors declared that this study received no financial support.

\section{References}

1. Merrill RM, Fugal S, Novilla LB, Raphael MC. Cancer risk associated with early and late maternal age at first birth. Gynecol Oncol 2005;96:583-93.

2. Elfayomy AK, Habib FA, Elkablawy MA. Role of hysteroscopy in the detection of endometrial pathologies in women presenting with postmenopausal bleeding and thickened endometrium. Arch Gynecol Obstet 2012;285:839-43.

3. Sousa R, Silvestre M, Almeida e Sousa L, Falcao F, Dias I, Silva T, et al. Transvaginal ultrasonography and hysteroscopy in postmenopausal bleeding: a prospective study. Acta Obstet Gynecol Scand 2001;80:856-62.

4. Smith-Bindman R, Kerlikowske K, Feldstein VA, Subak L, Scheidler J, Segal M, et al. Endovaginal ultrasound to exclude endometrial cancer and other endometrial abnormalities. JAMA 1998;280:1510-7.

5. Epstein E. Management of postmenopausal bleeding in Sweden: a need for increased use of hydrosonography and hysteroscopy. Acta Obstet Gynecol Scand 2004;83:89-95.

6. Goldstein RB, Bree RL, Benson CB, Benacerraf BR, Bloss JD, Carlos $\mathrm{R}$, et al. Evaluation of the woman with postmenopausal bleeding: Society of Radiologists in Ultrasound-Sponsored Consensus Conference statement. J Ultrasound Med 2001;20:1025-36.

7. Kalampokas T, Gregoriou O, Grigoriadis C, Iavazzo C, Zervakis A, Sofoudis C, et al. Comparing transvaginally defined endometrial thickness with hysteroscopic and histopathologic findings in asyptomatic postmenopausal women. Eur J Gynaecol Oncol 2012;33:508-11.

8. Dreisler E, Sorensen SS, Ibsen PH, Lose G. Value of endometrial thickness measurement for diagnosing focal intrauterine pathology in women without abnormal uterine bleeding. Ultrasound Obstet Gynecol 2009;33:344-8.

9. Wolfman W, Leyland N, Heywood M, Singh SS, Rittenberg DA, Soucy R, et al. SOGC Clinical Practice Guideline No. 249. . 2010;32:990-9.

10. Goldstein SR. Modern evaluation of the endometrium. Obstet Gynecol 2010;116:168-76

11. Schmidt T, Breidenbach M, Nawroth F, Mallmann P, Beyer IM, Fleisch MC, et al. Hysteroscopy for asymptomatic postmenopausal women with sonographically thickened endometrium. Maturitas 2009;62:176-8.

12. Grimes DA. Diagnostic dilation and curettage: a reappraisal. Am J Obstet Gynecol 1982;142:1-6.

13. Campaner AB, Piato S, Ribeiro PAG, Aoki T, Nadais RF, Prado RAA. Hysteroscopic findings in postmenopausal women with endometrial thickening diagnosed by transvaginal ultrasound. Rev Bras Ginecol Obstet 2004;26.

14. Lalchandani S, Phillips K. Evaluation of endometrial cavityinvestigation options., Reviews in Gynaecological Practice. Reviews in Gynaecological Practice 2003;3:165-70.

15. Hartman A, Wolfman W, Nayot D, Hartman M. Endometrial thickness in 1,500 asymptomatic postmenopausal women not on hormone replacement therapy. Gynecol Obstet Invest 2013;75:191-5. 
16. Lasmar RB, Dias R, Barrozo PR, Oliveira MA, Coutinho Eda S, da Rosa DB. Prevalence of hysteroscopic findings and histologic diagnoses in patients with abnormal uterine bleeding. Fertil Steril 2008;89:18037.

17. Ben-Yehuda OM, Kim YB, Leuchter RS. Does hysteroscopy improves upon the sensitivity of dilatation and curettage in the diagnosis of endometrial hyperplasia or carcinoma? 1998;68:4-7.

18. Lilienfeld DE, Stolley PD. Experimental epidemiology: randomized clinical trials. In: Foundation of epidemiology. Vol 8. Oxford, Oxford University Press; 1994;155-178.

19. Irwig L, Macaskill P, Glasziou P, Fahey M. Meta-analytic methods for diagnostic test accuracy. J Clin Epidemiol 1995;48:119-30.

20. Korkmazer E, Solak N, Ustunyurt E. Hysteroscopic assessment of postmenopausal endometrial thickening. Prz Menopauzalny 2014;13:330-3.

21. Gan DE, Jawan RA, Moy FM. Concordance between hysteroscopic impression and endometrial histopathological diagnosis. Prev Med 2013;57:S21-3.

22. Loizzi V, Bettocchi S, Vimercati A, Ceci O, Rossi C, Marello F, et al. Hysteroscopic evaluation of menopausal women with endometrial thickness of $4 \mathrm{~mm}$ or more. J Am Assoc Gynecol Laparosc 2000; $7: 191-5$

23. Litta P, Merlin F, Saccardi C, Pozzan C, Sacco G, Fracas M, et al. Role of hysteroscopy with endometrial biopsy to rule out endometrial cancer in postmenopausal women with abnormal uterine bleeding. Maturitas 2005;50:117-23.

24. Loiacono RM, Trojano G, Del Gaudio N, Kardhashi A, Deliso MA, Falco G, et al. Hysteroscopy as a valid tool for endometrial pathology in patients with postmenopausal bleeding or asymptomatic patients with a thickened endometrium: hysteroscopic and histological results. Gynecol Obstet Invest 2015;79:210-6.

25. Lee DO, Jung MH, Kim HY. Prospective comparison of biopsy results from curettage and hysteroscopy in postmenopausal uterine bleeding. J Obstet Gynaecol Res 2011;37:1423-6.

26. Bettocchi S, Nappi L, Ceci O, Santoro A, Fattizzi N, Nardelli C, et al. The role of office hysteroscopy in menopause. J Am Assoc Gynecol Laparosc 2004;11:103-6.

27. Spicer JM, Siebert I, Kruger TF. Postmenopausal bleeding: a diagnostic approach for both private and public sectors. Gynecol Obstet Invest 2006;61:174-8.
28. de Wit AC, Vleugels MP, de Kruif JH. Diagnostic hysteroscopy: a valuable diagnostic tool in the diagnosis of structural intra-cavital pathology and endometrial hyperplasia or carcinoma?. Six years of experience with non-clinical diagnostic hysteroscopy. Eur J Obstet Gynecol Reprod Biol 2003;110:79-82.

29. Butureanu SA, Socolov RM, Pricop F, Gafitanu DM. Diagnostic hysteroscopy in endometrial hyperplasia. Gynecol Obstet Invest 2005;59:59-61.

30. Angioni S, Loddo A, Milano F, Piras B, Minerba L, Melis GB. Detection of benign intracavitary lesions in postmenopausal women with abnormal uterine bleeding: a prospective comparative study on outpatient hysteroscopy and blind biopsy. J Minim Invasive Gynecol 2008;15:87-91.

31. Garuti G, Sambruni I, Colonnelli M, Luerti M. Accuracy of hysteroscopy in predicting histopathology of endometrium in 1500 women. J Am Assoc Gynecol Laparosc 2001;8:207-13.

32. Gambacciani M, Monteleone P, Ciaponi M, Sacco A, Genazzani AR. Clinical usefulness of endometrial screening by ultrasound in asymptomatic postmenopausal women. Maturitas 2004;48:421-4.

33. Breijer MC, Peeters JA, Opmeer BC, Clark TJ, Verheijen RH, Mol BW, et al. Capacity of endometrial thickness measurement to diagnose endometrial carcinoma in asymptomatic postmenopausal women: a systematic review and meta-analysis. Ultrasound Obstet Gynecol 2012;40:621-9.

34. Smith-Bindman R, Weiss E, Feldstein V. How thick is too thick? When endometrial thickness should prompt biopsy in postmenopausal women without vaginal bleeding. Ultrasound Obstet Gynecol 2004:24:558-65.

35. Giannella L, Mfuta K, Setti T, Boselli F, Bergamini E, Cerami LB. Diagnostic accuracy of endometrial thickness for the detection of intra-uterine pathologies and appropriateness of performed hysteroscopies among asymptomatic postmenopausal women. Eur J Obstet Gynecol Reprod Biol 2014;177:29-33.

36. Genc M, Genc B, Sahin N, Celik E, Turan GA, Gur EB, et al. Endometrial pathology in postmenopausal women with no bleeding. Climacteric 2015; 18:241-5.

37. de Godoy Borges PC, Dias R, Bonassi Machado R, Borges JB, Spadoto Dias D. Transvaginal ultrasonography and hysteroscopy as predictors of endometrial polyps in postmenopause. Womens Health (Lond) 2015;11:29-33.

38. Gambacciani M, Monteleone P, Ciaponi M, Sacco A, Genazzani AR. Clinical usefulness of endometrial screening by ultrasound in asymptomatic postmenopausal women. Maturitas 2004;48:421-4. 